\title{
The presence in experimental animals of a colon specific Mr 40000 protein(s) with relevance to ulcerative colitis
}

\author{
L Biancone, L S Wise, K M Das
}

\begin{abstract}
In patients with ulcerative colitis a colon tissue bound IgG and serum antibodies against an $\mathbf{M r}$ 40000 colonic protein(s) has been identified. Using an anti-Mr 40000 protein monoclonal antibody, $7 \mathrm{E}_{12} \mathrm{H}_{12}$, by an immunocytochemical method, the protein was localised in human tissue exclusively to colonic epithelial cells. In this study the presence of the $\mathbf{M r} \mathbf{4 0 0 0 0}$ protein was assessed in experimental animals by the direct and inhibition enzyme linked immunosorbent assays (ELISAs) using the anti-Mr 40000 protein monoclonal antibody, $7 \mathrm{E}_{12} \mathrm{H}_{12}$ (IgM isotype). In addition, a total of 129 specimens including colon, small intestine, gall bladder, biliary tract, and kidney from nine strains of rats and mice, and from human tissue were studied by the immunocytochemical method using $7 \mathrm{E}_{12} \mathrm{H}_{12}$. All colon specimens from both humans and animals reacted with $7 E_{12} H_{12}$ in the immunocytochemical and ELISA assays. None of the non-colonic organs reacted with $7 \mathrm{E}_{12} \mathrm{H}_{12}$. While in human colon $7 \mathrm{E}_{12} \mathrm{H}_{12}$ recognised the absorptive epithelial cells, in all the animals it recognised mainly the colonic goblet cells. Extracts of animal colon but not of small intestine inhibited the binding of $7 \mathrm{E}_{12} \mathrm{H}_{12}$ to the human colon extract. This study shows the presence of an organ specific Mr 40000 colonic epithelial protein(s) in humans and experimental animals. A differing cellular localisation of the $\mathbf{M r} \mathbf{4 0 0 0 0}$ protein(s) in human $v$ animal tissue was also shown. Further characterisation of the Mr 40000 protein(s) may provide important clues regarding the autoimmune mechanisms in ulcerative colitis.
\end{abstract}

Autoimmunity has been implicated in the pathogenesis of ulcerative colitis. ${ }^{1-11}$ The precise nature of the involved autoantigen(s) and antibodies is unknown, however. We earlier reported the presence of an IgG antibody bound to colonic tissue from patients with ulcerative colitis and termed it CCA-IgG or colitis colon associated IgG antibody. ${ }^{12}$ The CCA-IgG preferentially binds to colonic tissue extracts ${ }^{13}$ containing an $\mathrm{Mr} 40000$ protein(s) from both normal and diseased colon. ${ }^{14}$ Eluted tissue bound IgG from Crohn's disease or normal colon did not recognise this protein.

Circulating antibodies reactive against the $\mathrm{Mr}$ 40000 protein(s) have also been recently shown in patients with ulcerative colitis. ${ }^{15}$ Using an anti$\mathrm{Mr} 40000$ protein monoclonal antibody $\left(7 \mathrm{E}_{12} \mathrm{H}_{12}, \mathrm{IgM}\right.$ isotype) in an immunocytochemical analysis, the protein has been localised in human tissue to colonic epithelial cells but not in non-colonic epithelial tissue from 13 other organs. ${ }^{16}$ These findings suggest that this protein represents at least one of the autoantigen(s) in ulcerative colitis.

In this study we investigated the presence of the $\mathrm{Mr} 40000$ protein in various experimental animals. The organ and species specificity of the $\mathrm{Mr} 40000$ protein was evaluated by the immunocytochemical method, direct enzyme linked immunosorbent assay (ELISA), and inhibition ELISA assays, using an anti-Mr 40000 protein monoclonal antibody.

\section{Method}

IMMUNOCYTOCHEMICAL LOCALISATION OF THE MR 40000 PROTEIN IN ANIMAL TISSUE

\section{Tissue specimens}

A total of 129 formalin fixed tissue specimens were obtained from normal human colon (5) and small intestine (3); Wistar rat colon (11) and small intestine (5); Lewis rat colon (12), small intestine (3), kidney (4), and biliary tract (6); Sprague Dawley rat colon (10) and small intestine (4); BALB/c mouse colon (12), small intestine (7), biliary tract (6), gall bladder (4), and kidney (4); SJL mouse colon (9), small intestine (4), and biliary tract (4); B10.D2 mouse colon (4); DB.A2 mouse colon (4); B6.D2.F11 mouse colon (4); and B6 mouse colon (4). Samples of human colon and ileal tissue were obtained from normal subjects who underwent colonoscopy. The animals were sacrificed by cervical dislocation and specimens of colon, small intestine, kidneys, and biliary tract were fixed in $10 \%$ formalin. All animals were males, 4 to 8 weeks old.

\section{IMMUNOPEROXIDASE TECHNIQUE USING THE} ANTI-MR 40000 MONOCLONAL ANTIBODY, 7 $\mathrm{E}_{12} \mathrm{H}_{12}$ Preliminary experiments were performed on human and animal tissues to evaluate the effect of several fixation procedures on antigen preservation. Because formalin fixation did not affect the antigen(s) and gave the best preservation, formalin fixed, paraffin embedded tissues were used. Five $\mu \mathrm{m}$ sections were deparaffinised, rehydrated, and incubated for 30 minutes in $0 \cdot 1 \mathrm{~mol} / \mathrm{l}$ phosphate buffer, $\mathrm{pH} 7 \cdot 4$, containing $0.3 \% \mathrm{H}_{2} \mathrm{O}_{2}$ in order to block the endogenous peroxidase activity. After washings in phosphate buffer, sections were incubated for two hours with diluted $(1 / 50)$ normal goat serum $(100 \mu \mathrm{l})$ to block non-specific binding to the section. After 
incubation excess serum was wiped from around the sections, and the sections were incubated overnight with different dilutions of the monoclonal antibody $7 \mathrm{E}_{12} \mathrm{H}_{12}$ (IgM isotype). The dilution for $7 \mathrm{E}_{12} \mathrm{H}_{12}$ ranged from 1:20 through $1: 300$. After washings with $0 \cdot 1 \mathrm{~mol} / \mathrm{l}$ phosphate

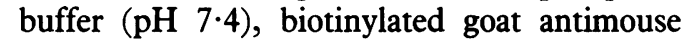
IgM (Vector Lab, Burlingham CA) was added for 90 minutes, followed, after washings in phosphate buffer, by avidin-biotin-peroxidase complex (ABC, Vector Lab, Burlingame CA) for 90 minutes. The reaction was then developed by incubating the sections in $1 \mathrm{mg} / \mathrm{ml}^{3}-3^{\prime}$ diaminobenzidine in $0.1 \mathrm{~mol} / \mathrm{l}$ Tris- $\mathrm{HCl}, \mathrm{pH} 7 \cdot 6$, $0.02 \% \mathrm{H}_{2} \mathrm{O}_{2}$ for 10 minutes in the dark. Slides were then washed, dehydrated, and mounted. All incubations were performed at room temperature except for the overnight incubation, which was at $4^{\circ} \mathrm{C}$. Other sections from the same tissue block were deparaffinised, rehydrated, and incubated with an unrelated IgM monoclonal antibody as control. Sections were also stained with haematoxylin and eosin for routine histology.

\section{EXTRACTION OF TISSUE PROTEINS}

For human samples, normal segments of colon specimens from two patients who underwent colectomy for colonic carcinoma were used. The colon or small intestine from animals was removed and rinsed with phosphate buffered saline. The cleaned tissue was weighed and the colon transferred to a cold disposable tube, to which, per $\mathrm{g}$ of tissue, was added $2.5 \mathrm{ml}$ of ice cold phosphate buffered saline containing $0.5 \mu \mathrm{g} / \mathrm{ml}$ leupeptin, $5 \mu \mathrm{g} / \mathrm{ml}$ pepstatin, $2 \mathrm{mmol} / \mathrm{l}$ ethylenediamine tetra-acetate and $2 \mathrm{mmol} / \mathrm{l}$ phenyl methyl sulphonyl fluoride. The tissues were homogenised in an ice bath by Polytron for

TABLE I Immunoperoxidase (129 tissue specimens tested)

\begin{tabular}{|c|c|c|c|c|c|c|c|c|}
\hline & & \multicolumn{7}{|c|}{$7 E_{12} H_{12}$ monoclonal antibody dilutions } \\
\hline & & $1: 20$ & $1: 40$ & $1: 75$ & $1: 80$ & $1: 100$ & $1: 200$ & $1: 300$ \\
\hline \multicolumn{9}{|l|}{ Wistar rat } \\
\hline Colon & (11) & + & + & + & + & + & + & - \\
\hline Small intestine & (5) & - & - & - & & & & \\
\hline \multicolumn{9}{|l|}{ Lewis rat } \\
\hline Colon & (12) & + & + & + & + & + & + & + \\
\hline Small intestine & (3) & - & - & - & - & & & \\
\hline Biliary tract & (6) & - & - & _ & & & & \\
\hline Kidney & (4) & - & - & - & & & & \\
\hline \multicolumn{9}{|l|}{ Sprague } \\
\hline \multicolumn{9}{|l|}{ Dawley rat } \\
\hline Colon & (10) & + & + & + & + & + & + & + \\
\hline Small intestine & (4) & - & - & & & & & \\
\hline \multicolumn{9}{|l|}{ BALB/c mice } \\
\hline Colon & (12) & + & + & + & + & + & + & + \\
\hline Small intestine & (7) & - & - & - & - & & & \\
\hline Biliary tract & (6) & - & - & - & - & & & \\
\hline Gall bladder & (4) & - & - & - & & & & \\
\hline Kidney & (4) & - & - & - & & & & \\
\hline \multicolumn{9}{|l|}{ SJL mice } \\
\hline Colon & (9) & + & + & + & + & + & + & - \\
\hline Small intestine & (4) & - & - & - & - & & & \\
\hline Biliary tract & (4) & - & - & - & - & & & \\
\hline \multicolumn{9}{|l|}{ B10.D2 mice } \\
\hline Colon & (4) & & & & & & + & - \\
\hline DB.A2 mice & & & & & & & & \\
\hline \multicolumn{9}{|l|}{ Colon } \\
\hline Colon & (4) & & & & & & + & _- \\
\hline \multicolumn{9}{|l|}{ B6 mice } \\
\hline Colon & (4) & & & & & & + & - \\
\hline \multicolumn{9}{|l|}{ Human } \\
\hline Colon & (5) & & + & + & & + & + & - \\
\hline Small intestine & (3) & & - & - & - & & & \\
\hline
\end{tabular}

Colon specimens $n=75$; small intestine specimens $n=26$; biliary tract specimens $n=16$; gall bladder specimens $n=4$; kidney specimens $n=8 ;+=$ positive staining; $-=$ negative staining.
5 minutes. The homogenate was clarified by centrifugation at $3000 \mathrm{~g}$ for 30 minutes at $4^{\circ} \mathrm{C}$ and further by ultracentrifugation at $100000 \mathrm{~g}$ for one hour at $4^{\circ} \mathrm{C}$. Finally, the protein concentration of the supernatant fraction was evaluated by the Bradford protein assay (BIO-RAD).

EXAMINATION OF HUMAN AND ANIMAL TISSUE EXTRACTS FOR THE PRESENCE OF MR 40000 PROTEIN USING $7 \mathrm{E}_{12} \mathrm{H}_{12}$ BY DIRECT ELISA

ELISA plates were coated with $0 \cdot 2 \mu \mathrm{g}$ of total tissue extracts per well and diluted in carbonate

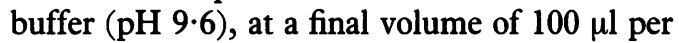
well. As antigen, we used colon and small intestine tissue extracts from humans (2), Wistar rats (3), Lewis rats (3), Sprague Dawley rats (3), BALB/c mice (5), SJL mice (2), DB.A2 mice (2), B10.D2 mice (2), B6.D2.F11 mice (2), and B6 mice (2). As blank, additional wells were coated with $100 \mu \mathrm{l}$ bovine serum albumin $(0.5 \mu \mathrm{g} /$ well $)$. After overnight incubation at $4^{\circ} \mathrm{C}$, non-specific binding was blocked with $100 \mu \mathrm{l}$ of $0.1 \mathrm{~mol} / \mathrm{l}$ phosphate buffered saline ( $\mathrm{pH} 7 \cdot 4)$ per well with $2 \%$ bovine serum albumin, for two hours at $37^{\circ} \mathrm{C}$. After three washings in phosphate buffered saline $/ 0.05 \%$ Tween $20(200 \mu \mathrm{l} /$ well $)$, as first antibody, different dilutions of $7 \mathrm{E}_{12} \mathrm{H}_{12}(1: 100,1: 200$, and $1: 400)$ were used (100 $\mu \mathrm{l} /$ well). After two hours' incubation at $37^{\circ} \mathrm{C}$ and washings in phosphate buffered saline/ $0.05 \%$ Tween 20 , as second antibody, $100 \mu l$ of alkaline phosphatase conjugated goat antimouse IgM was added to each well (at 1:1000 dilution). After one hour incubation at 37:C and washings with phosphate buffered saline $/ 0 \cdot 05 \%$ Tween $20,100 \mu \mathrm{l}$ of substrate p-nitrophenylphosphate, disodium (Sigma 104, Chemical Co, St Louis MO) was added to each well $(5 \mu \mathrm{g} / \mathrm{ml})$ and incubated for one hour at room temperature. The plates were then read at $405 \mathrm{~nm}$ in a Vmax ELISA reader (Molecular Devices). Results are expressed as mean optical density of triplicate determinations.

CROSS REACTIVITY BETWEEN ANIMAL AND HUMAN COLON EXTRACTS: INHIBITION ELISA

Inhibition ELISA was performed by following the method described by Klatser et a ${ }^{17}$ with some modifications. Wells of the ELISA plates were coated with $0.2 \mu \mathrm{g}$ Lewis rat colon extract diluted in carbonate buffer (pH 9.6), at a final volume of $100 \mu \mathrm{l}$ per well. As blank, additional wells were coated with $100 \mu \mathrm{l}$ of bovine serum albumin $(0.5 \mu \mathrm{g} /$ well $)$. Plates were then incubated overnight at $4^{\circ} \mathrm{C}$. A blocking agent, phosphate buffered saline with $2 \%$ bovine serum albumin (100 $\mu \mathrm{l} /$ well), was then added to each well and plates were incubated for two hours at $37^{\circ} \mathrm{C}$. The presence of a specific inhibition of the binding of the Lewis rat colon extract with $7 \mathrm{E}_{12} \mathrm{H}_{12}$ by colon and small intestine extracts from humans (2), Wistar rats (3), Lewis rats (3), Sprague Dawley rats (3), BALB/c mice (5), and SJL mice (2), was tested by evaluating their ability to compete with the Lewis rat colon extract for binding with $7 \mathrm{E}_{12} \mathrm{H}_{12}$. For this purpose equal volumes of $7 \mathrm{E}_{12} \mathrm{H}_{12}$ diluted at $1: 50$ in $50 \mu$ l (final dilution $1: 100$ ) were incubated for 

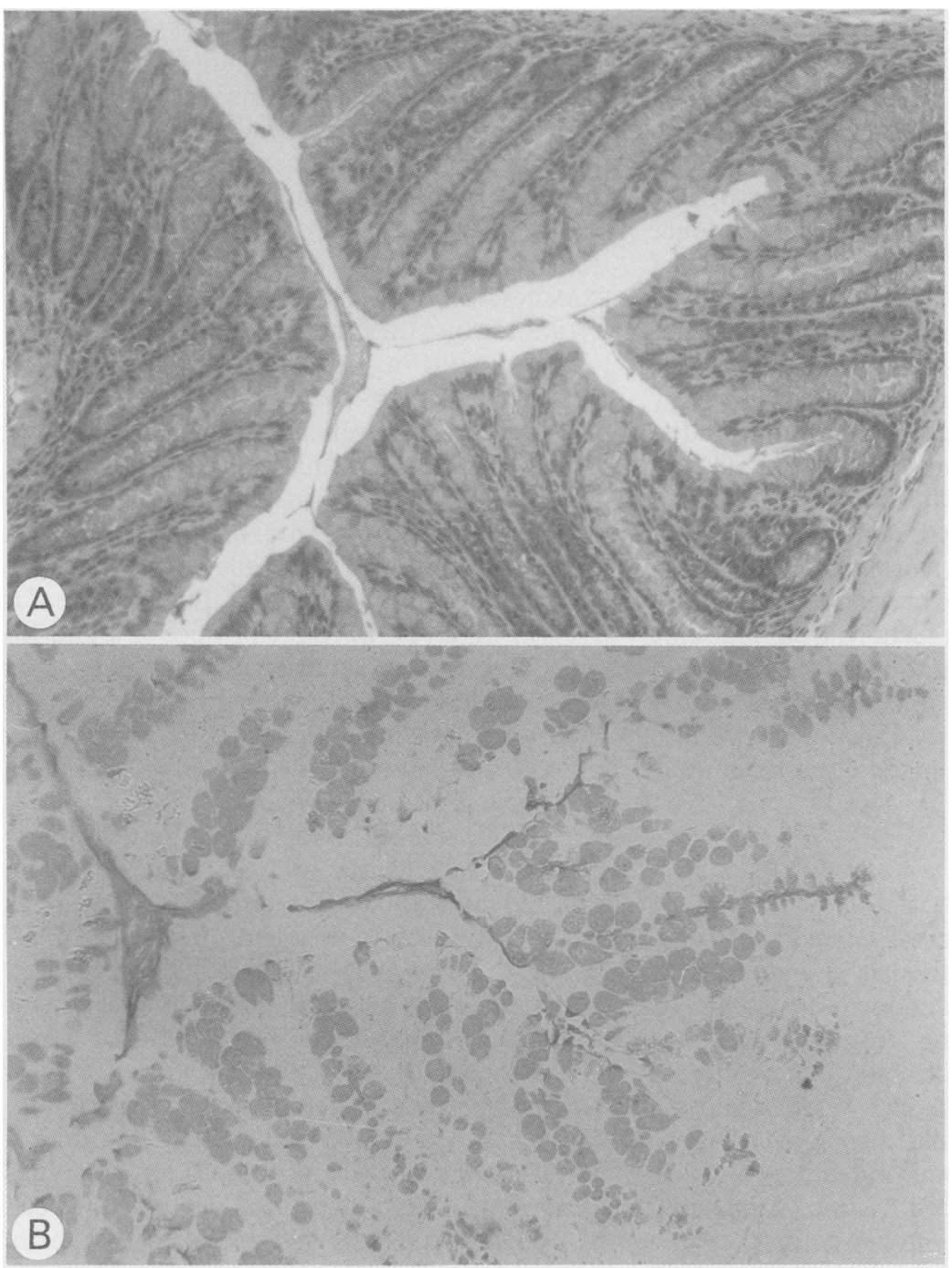

Figure 1: (A) Haematoxylin and eosin staining against $a$ $B A L B / c$ mouse colon specimen.

Immunocytochemical analysis using the $7 \mathrm{E}_{12} \mathrm{H}_{12}$ monoclonal antibody with $B A L B / c$ mouse colon $(B)$ and human colon $(C)$. The immunoreactivity of $7 E_{12} H_{12}$ against the BALB/ c mouse colon specimen $(B)$ is mainly localised to colonic goblet cells (original magnification $\times 20$ ). In human colonic epithelial cells $(C)$, however, the immunoreactivity of $7 E_{12} H_{12}$ is more concentrated at the basolateral areas of the plasma membrane (original magnification $\times 20$ ).

three hours at $37^{\circ} \mathrm{C}$ with $50 \mu$ l of the tissue extracts at different serial concentrations. Triplicate wells were incubated with 11 serial dilutions of the tissue extracts - for example, $0.003 \mu \mathrm{g}$ to $4 \mu \mathrm{g}$ per well. After washing three times with phosphate buffered saline $/ 0.05 \%$ Tween 20, the wells were incubated with alkaline phosphatase conjugated goat antimouse IgM followed by p-nitrophenylphosphate, as described in the direct ELISA. In separate experiments inhibition ELISA assays were performed after coating the plates with human colon extracts and competing with animal tissue extracts as described above.

\section{Results}

IMMUNOCYTOCHEMICAL LOCALISATION OF THE MR 40000 PROTEIN BY $7 \mathrm{E}_{12} \mathrm{H}_{12}$ MONOCLONAL ANTIBODY

All 75 colon specimens from mice, rats, and humans reacted with $7 \mathrm{E}_{12} \mathrm{H}_{12}$, but none of the 26 small intestine specimens from human or any of the experimental animals reacted with $7 \mathrm{E}_{12} \mathrm{H}_{12}$ (Table I). Kidney ( 8 specimens), biliary tract (16 specimens), and gall bladder (4 specimens) from the rats and mice did not react with $7 \mathrm{E}_{12} \mathrm{H}_{12}$. A difference in the degree of immunoreactivity against the $\mathrm{Mr} 40000$ protein by $7 \mathrm{E}_{12} \mathrm{H}_{12}$ was evident among the different species (Table I). Colon specimens from Lewis rats, Sprague Dawley rats, and BALB/c mice reacted with $7 \mathrm{E}_{12} \mathrm{H}_{12}$ when used at a higher dilution (1:300), but other colon specimens including those from humans were negative at this dilution. Figure $1 \mathrm{~B}$ shows that in animal colon $7 \mathrm{E}_{12} \mathrm{H}_{12}$ reacted mainly with the goblet cells. In human colon, however, immunoreactivity was found in the absorptive epithelial cells, mainly along the apical and basolateral areas of the plasma membrane (Figure 1C). Neither the epithelial cells nor the goblet cells in the small intestine from humans and animals reacted with $7 \mathrm{E}_{12} \mathrm{H}_{12}$.

PRESENCE OF MR 40000 PROTEIN IN THE HUMAN AND ANIMAL TISSUE EXTRACTS AS DETECTED BY THE DIRECT ELISA

To further examine the presence and quantify the $\mathrm{Mr} 40000$ protein in human and animal colon extracts, a direct ELISA assay using $7 \mathrm{E}_{12} \mathrm{H}_{12}$ has been developed. The specific binding of $7 \mathrm{E}_{12} \mathrm{H}_{12}$ against colon and small intestine extracts from all the species is shown in Figure 2. The direct ELISA assay confirmed the findings of immunoperoxidase staining, indicating the presence of the specific immunoreactivity of $7 \mathrm{E}_{12} \mathrm{H}_{12}$ against all the colon specimens tested from both human and animal samples. On the contrary, none of the small intestine extracts reacted with $7 \mathrm{E}_{12} \mathrm{H}_{12}$. The data also showed a wide variation in the degree of binding of $7 \mathrm{E}_{12} \mathrm{H}_{12}$ to the $\mathrm{Mr} 40000$ colonic protein(s) present in the colon extracts among the different species and strains. Higher immunoreactivity of $7 \mathrm{E}_{12} \mathrm{H}_{12}$ was observed against colon extracts from $\mathrm{BALB} / \mathrm{c}$ mice and Lewis rats (Fig 2).

CROSS REACTIVITY BETWEEN ANIMAL AND HUMAN COLON EXTRACTS: INHIBITION ELISA

The cross reactivity of the antigen(s) present in the colon from humans, Wistar rats, Lewis rats, Sprague Dawley rats, BALB/c mice, and SJL mice was further investigated by using different colon extracts to compete with the Lewis rat colon extract and human colon extract for binding against $7 \mathrm{E}_{12} \mathrm{H}_{12}$ in an inhibition ELISA assay. Figure 3 and Table II show the cross reactivity among various species and the relative differences in the expression of the immunoreactive epitope(s). As Table II shows all the colon specimens tested were capable of inhibition, although at different concentrations. A $50 \%$ inhibition of the binding of $7 \mathrm{E}_{12} \mathrm{H}_{12}$ to the Lewis 


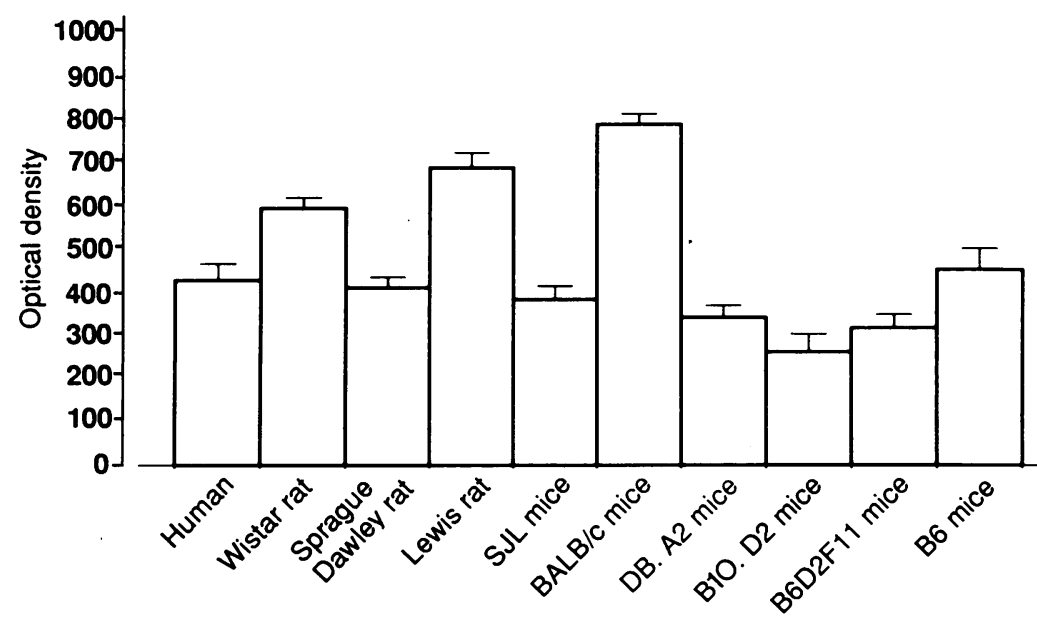

Figure 2: Immunoreactivity of $7 E_{12} H_{12}(1: 100)$ against human and animal tissue extracts as evaluated by direct ELISA. The histograms show optical density values (mean (SEM)) from three different experiments. Blank values (range 0.070-0.090) have been deducted. The means $(S E M)$ for different groups are: human 0.425 (0.031), Wistar rat 0.590(0.092), Sprague Dawley rat 0.408 (0.070), Lewis rat 0.684 (0.092), SfL mice 0.380 (0.090), BALB/c mice $0.785(0.154), D B . A 2$ mice 0.355 (0.042), B10.D2 mice 0.252 (0.042), B6.D2.F11 0.311 $(0.031)$, B6 mice 0.450 (0.074). All the colon extracts reacted with $7 E_{12} H_{12}$, and the higher immunoreactivity was present in colon extracts from $B A L B / c$ mice and Lewis rats. None of the small intestine extracts reacted with $7 E_{12} H_{12}$ (not shown here).

rat colon extract was achieved with $0.022 \mu \mathrm{g}$ of autologous colon extract, though 0.054 to $1 \mu \mathrm{g}$ of colon extracts from the other species were needed to induce the same degree of inhibition (Table II). Inhibition of the binding of $7 \mathrm{E}_{12} \mathrm{H}_{12}$ to Lewis rat colon extract by different concentrations of colon and small intestine extracts from human, Lewis rats, and BALB/c mice is shown in Figure 3. These data suggest a difference in the affinity of the $\mathrm{Mr} 40000$ colonic protein to $7 \mathrm{E}_{12} \mathrm{H}_{12}$ among the different species. The highest specific immunoreactivity against $7 \mathrm{E}_{12} \mathrm{H}_{12}$ was present in the Lewis rats and BALB/c mice colon extracts (Fig 3 and Table II). The small intestine extracts from humans and animals did not interfere with the binding of $7 \mathrm{E}_{12} \mathrm{H}_{12}$ with Lewis rat colon extract. The binding of $7 \mathrm{E}_{12} \mathrm{H}_{12}$ to human colon extract was also inhibited by all the animal colon extracts but

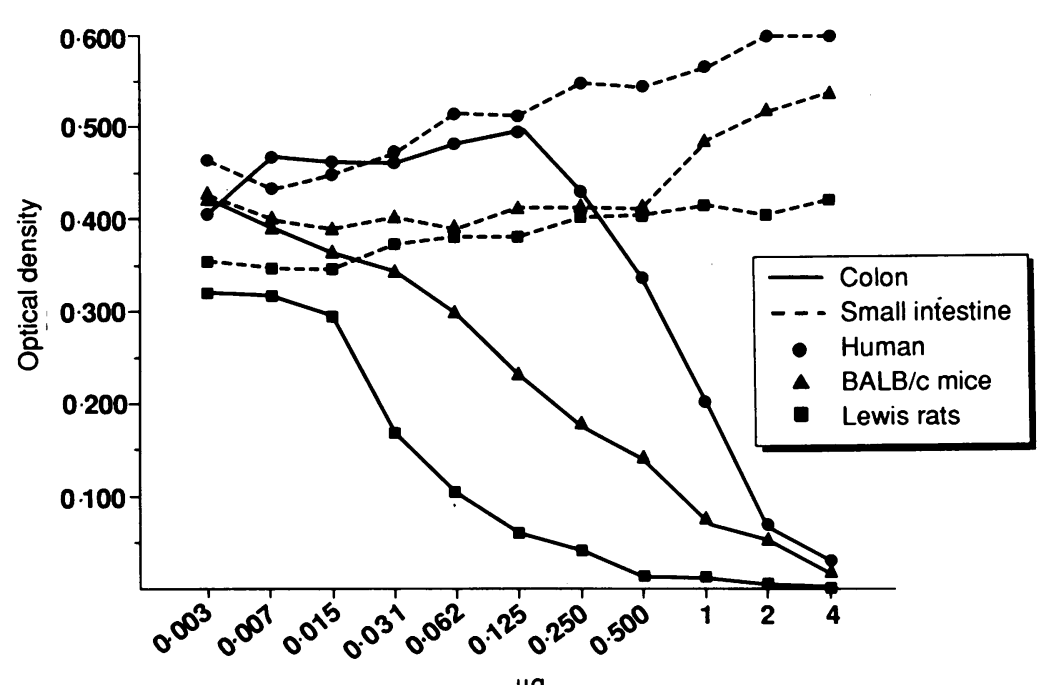

Figure 3: Inhibition ELISA: the inhibition of $7 E_{12} H_{12}$ binding to Lewis rat colon extract by serial dilutions of colon or small intestine extract from humans, Lewis rats, and $B A L B / c$ mice. All the colon extracts, and none of the small intestine extracts, inhibited the binding of $7 E_{12} H_{12}$ to the antigen coating the plate. The inhibition was stronger using the Lewis rats and $B A L B / C$ mice colon extracts. not small intestine extracts (Table II). The lowest amount of protein required to induce a $50 \%$ inhibition of the binding of $7 \mathrm{E}_{12} \mathrm{H}_{12}$ to the human colon extract was observed with colon extract from Lewis rats followed by homologous colon extract.

\section{Discussion}

In this study the presence of an $\mathrm{Mr} 40000$ associated protein(s) has been shown in the colon from humans and various animals using the anti$\mathrm{Mr} 40000$ monoclonal antibody $7 \mathrm{E}_{12} \mathrm{H}_{12}$. The organ specificity of this protein in human tissue was shown earlier, ${ }^{16}$ and in this study we have identified the protein in various experimental animals and confirmed the organ specificity. Using serial dilutions a different degree of expression of the $7 \mathrm{E}_{12} \mathrm{H}_{12}$ reactive epitope on $\mathrm{Mr}$ 40000 colonic protein(s) was observed among the different species. the highest specific immunoreactivity against $7 \mathrm{E}_{12} \mathrm{H}_{12}$ was present in colon from Lewis rats and $\mathrm{BALB} / \mathrm{c}$ mice. Results from immunoperoxidase reactivity in the immunocytochemical analysis and direct and inhibition ELISA assays using $7 \mathrm{E}_{12} \mathrm{H}_{12}$ indicated that the $\mathrm{Mr} 40000$ protein is present only in colon from all the species and not in small intestine, biliary tract, and kidney.

In this study heterogeneity in the localisation of the $\mathrm{Mr} 40000$ colonic protein(s)/epitopes in human $v$ animals was noted. In humans $7 \mathrm{E}_{12} \mathrm{H}_{12}$ reacts with biliary epithelium in addition to colon, ${ }^{18}$ but in the rats and mice none of the 20 specimens of biliary tract and gall bladder reacted with $7 \mathrm{E}_{12} \mathrm{H}_{12}$. Furthermore, results from immunoperoxidase reactivity indicated that while in humans $7 \mathrm{E}_{12} \mathrm{H}_{12}$ mainly recognised the columnar colonic epithelium (confirming our previous data $\left.{ }^{16}\right)$, in all the animals $7 \mathrm{E}_{12} \mathrm{H}_{12}$ reacted with the colonic goblet cells. This finding may be explained on the basis of a common origin of all cell types in the colonic epithelium from undifferentiated cells at the crypt base in experimental animals. ${ }^{19}$ The unitarian theory of a pluripotential stem cell postulates that columnar, goblet, endocrine, and Paneth cells all develop from the same precursor. ${ }^{19}$ It can be postulated that the $7 \mathrm{E}_{12} \mathrm{H}_{12}$ reactive $\mathrm{Mr} 40000$ epitope is expressed at different stages of cell differentiation in colon from humans $v$ animals. A second monoclonal antibody, $7 \mathrm{E}_{6} \mathrm{~A}_{5},{ }^{20}$ which recognises the intestinal goblet cells in humans reacted with neither colon nor small intestine from animals in the present study (data not shown). Such a species specificity was reported for goblet cell mucin, where human was cross reactive with dog, monkey, and rabbit mucin, but not with mucin of rat, pig, toad, and oyster."

The study shows the presence of a unique $\mathrm{Mr}$ 40000 colonic protein(s) in humans and different animal species and confirms its organ specificity. The results also suggest a heterogeneity of this protein in humans $v$ animals. These are shown both by immunocytochemical analysis and by an ELISA. In addition, animal colon extracts, and not small intestinal extracts, inhibited the binding of $7 \mathrm{E}_{12} \mathrm{H}_{12}$ with the human colon extracts, suggesting the cross reactivity between the different species. As ulcerative colitis is almost 
TABLE II Inhibition of binding of Lewis rat and human colon extracts with $7 E_{12} H_{12}$

\begin{tabular}{|c|c|c|c|}
\hline Species & Tissue & $\%$ Inhibition & Protein concentration $(\mu g)$ \\
\hline \multicolumn{4}{|l|}{ Lewis rat colon: } \\
\hline \multirow{2}{*}{ Lewis rat } & Colon & $50 \%$ & 0.022 \\
\hline & Small intestine & None & - \\
\hline \multirow{2}{*}{ Wistar rat } & Colon & $50 \%$ & 0.055 \\
\hline & Small intestine & None & - \\
\hline \multirow{3}{*}{$\begin{array}{l}\text { Sprague } \\
\text { Dawley rat }\end{array}$} & & & \\
\hline & Colon & $50 \%$ & 0.070 \\
\hline & $\begin{array}{l}\text { Small intestine } \\
\text { Colon }\end{array}$ & $\begin{array}{l}\text { None } \\
50 \%\end{array}$ & $\overline{0} .054$ \\
\hline BALB/c mice & Small intestine & None & - \\
\hline \multirow[t]{2}{*}{ SJL mice } & Colon & $50 \%$ & $1 \cdot 2$ \\
\hline & Small intestine & None & - \\
\hline \multirow[t]{2}{*}{ Human } & Colon & $50 \%$ & $0 \cdot 280$ \\
\hline & Small intestine & None & - \\
\hline \multirow{2}{*}{$\begin{array}{l}\text { Human colon: } \\
\text { Lewis rat }\end{array}$} & Colon & $50 \%$ & 0.030 \\
\hline & Small intestine & None & - \\
\hline \multirow[t]{2}{*}{ Wistar rat } & Colon & $50 \%$ & $0 \cdot 219$ \\
\hline & Small intestine & None & - \\
\hline \multirow{2}{*}{$\begin{array}{l}\text { Sprague } \\
\text { Dawley rat }\end{array}$} & & & \\
\hline & $\begin{array}{l}\text { Colon } \\
\text { Small intestine }\end{array}$ & $\begin{array}{l}50 \% \\
\text { None }\end{array}$ & $0 \cdot 125$ \\
\hline \multirow[t]{2}{*}{$\mathrm{BALB} / \mathrm{c}$ mice } & Colon & $50 \%$ & $0 \cdot 109$ \\
\hline & Small intestine & None & - \\
\hline \multirow[t]{2}{*}{ SJL mice } & Colon & $50 \%$ & 0.438 \\
\hline & Small intestine & None & \\
\hline \multirow[t]{2}{*}{ Human } & Colon & $50 \%$ & 0.046 \\
\hline & Small intestine & None & - \\
\hline
\end{tabular}

exclusively localised to colonic mucosa, the finding of the organ specificity of the $\mathrm{Mr} 40000$ colonic protein(s) may be important in the pathogenesis of the disease. Furthermore, the presence of colon tissue bound ${ }^{14}$ and circulating IgG antibodies ${ }^{15}$ reactive to the $\mathrm{Mr} 40000$ protein(s) in patients with ulcerative colitis suggest that the $\mathrm{Mr} 40000$ protein acts as at least one autoantigen(s) in ulcerative colitis. Circulating antibodies from ulcerative colitis react against rat colonic epithelial cells in fluorescence activated cell sorter analysis ${ }^{8}$ and also mediate antibody dependent cell mediated cytolysis against rat colonic epithelial cells. ${ }^{22}$ The $\mathrm{Mr} 40000$ protein has been localised on the plasma membrane of human colon epithelial cells by immunoperoxidase and immunoelectromicroscopy ${ }^{16}$ and recently by fluorescence activated cell sorter on the surface of a colon cancer cell line DLD-1..$^{23}$ Sera from ulcerative colitis patients also showed antibody dependent cell mediated cytolysis against DLD-1 cells. ${ }^{24}$ It is not known, however, whether this is related to the recognition of the $\mathrm{Mr} 40000$ colonic protein(s) in the rat colonic epithelial cells and the colon cancer cell line. Future studies focusing on biochemical characterisation of the $40000 \operatorname{protein}(\mathrm{s})$, and the immunoreactive epitope(s), from human and animal colon may provide important clues about the autoimmune mechanisms in ulcerative colitis. The results of this study may also help in the development of an animal model of colitis using the $\mathrm{Mr} 40000$ protein(s).

This work is supported by research grants from the UMDNJ Foundation, National Foundation for Ileitis and Colitis, and N Cancer Commission. LB received a fellowship award from the Instituto-Pasteur Fondazione Cenci-Bolognetti, Rome, Italy.

\section{Addendum}

Recently, after fixation of animal colon with $4 \%$ paraformaldehyde in phosphate buffered saline $(\mathrm{pH} 7 \cdot 2)$ for three hours at $4^{\circ} \mathrm{C}$ we observed that $7 \mathrm{E}_{12} \mathrm{H}_{12}$ reacted with columnar epithelial cells in addition to goblet cells. Small intestine, biliary tract, and skin from the animals were still negative.

1 Broberger O, Perlmann P, Autoantibodies in human ulcerative colitis. F Exp Med 1958; 110: 657-74.

2 Broberger O, Perlmann P. In vitro studies of ulcerative colitis I. Reactions of patients' serum with human fetal colon cells in tissue culture. $\mathcal{F}$ Exp Med 1963; 117: 705-15.

3 Perlmann $P$, Broberger $O$. In vitro studies of ulcerative colitis. II. Cytotoxin action of white blood cell from patients on human fetal colon cells. $\mathcal{F}$ Exp Med 1963; 117: 717-33.

4 Lagercrantz R, Hammarstrom S, Perlmann P. Immunological studies in ulcerative colitis. III. Incidence of antibodies to colon-antigen in ulcerative colitis and other gastrointestinal disease. Clin Exp Immunol 1966; 1: 263-76.

5 Carlsson HE, Sundblad G, Hammarstrom S, Perlmann P, Gustaffson BE. Immunological studies in ulcerative colitis extract, fractionation and immunological characterization of germ-free rat colon antigen. Arch Biochem Biophys 1978; 187: $366-75$.

6 Zeromsky J, Perlmann P, Lagercrantz R, Hammarstrom S. Immunological studies in ulcerative colitis. VII. Anticolon Immunol 1970; 7: 469-75.

7 Perlmann P, Hammarstrom S, Lagercrantz R, Cambell D. Autoantibodies to colon in rats and human ulcerative colitis: cross reactivity with E. coli 0:14 antigen. Proceedings of the Society for Experimental Biology and Medicine 1967; 125: 975-80.

8 Hibi TB, Aiso M, Ishikawa M, et al. Circulating antibodies to the surface antigens on colon epithelial cells in ulcerative colitis. Clin Exp Immunol 1983; 54: 163-8.

9 Aronson RA, Cooke SL, Roche JK. Sensitization to epithelial antigens in chronic mucosal inflammatory disease. I. Purification, characterization and immunoreactivity of murine epithelial cell-associated components (ECAC). F Immunol epithelial cell-associat

10 Brandtzaeg P, Baklien K, Fausa O, Hoel PS. Immunohistochemical characterization of local immunoglobulin formation in ulcerative colitis. Gastroenterology 1974; 66: 1123-36.

11 Scott BB, Goodell A, Stephenson P, Jenkin D. Rectal mucosa plasma cells in inflammatory bowel disease. Gut 1983; 24 519-24.

12 Das KM, Dubin R, Nagai T. Isolation and characterization of colonic tissue-bound antibodies from patients with idiopathic ulcerative colitis. Proc Natl Acad Sci USA 1978; 75: 4528-32.

13 Nagai T, Das KM. Detection of colonic antigen(s) in tissue from ulcerative colitis using purified colitis colon tissuefrom ulcerative colitis using purified colitis colon tissue-
bound IgG (CCA-IgG). Gastroenterology 1981; 81: 463-70.

14 Takahashi F, Das KM. Isolation and characterization of a colonic autoantigen specifically recognized by colon tissuebound immunoglobulin $\mathrm{G}$ from idiopathic ulcerative colitis f Clin Invest 1985; 76: 311-8.

15 Takahasi F, Shah HS, Wise LS, Das KM. Circulating antibodies against human colonic extract enriched with a $40 \mathrm{kDa}$ protein in patients with ulcerative colitis. Gut 1990 31: $1016-20$.

16 Das KM, Vecchi M, Sakamaki S, Diamond B. The production and characterization of monoclonal antibodies to a human colonic antigen associated with ulcerative colitis: cellular localization of the antigen using the monoclonal antibody. Iocalization of the antigen using $1987 ; 139$ : 77-84.

17 Klatser PR, Le Wit MY, Kolk AH. An ELISA-inhibition test using monoclonal antibody for the serology of leprosy. Clin Exp Immunol 1985; 62: 468-73.

18 Das KM, Vecchi M, Sakamaki S. A shared and unique epitope(s) on human colon, skin, and biliary epithelium detected by a monoclonal antibody. Gastroenterology 1990 98: 464-9.

19 Cheng H, Leblond CP. Origin, differentiation and renewal of the four main epithelial cell types in the mouse small intestine. V. Unitarian theory of the origin of the four epithelial cell types. Am $\mathcal{F}$ Anat 1974; 141: 537-62.

20 Vecchi M, Sakamaki S, Diamond B, Novikoff AB, Novikoff PM, Das KM. Development of a monoclonal antibody specifically reactive to gastrointestinal goblet cells. Proc Natl specifically reactive to gastrointesin

21 Qureshi R, Forstner GG, Forstner JF. Radioimmunoassay of human intestinal goblet cell mucin. Investigation of mucus from different organ and species. $\mathcal{F}$ Clin Invest 1979; 64 $1149-51$.

22 Hibi T, Ohara M, Toda K, et al. Establishment of human anticolon antibody producing cell lines transformed by Epstein-Barr virus. In: MacDermott RP, ed. Inflammatory bowel disease, current status and future approach. New York: Elsevier, 1988: 77-81.

23 Das KM, Squillante L, Roberstron F. An increased expression of the $\mathrm{Mr} 40,000$ colonic epithelial protein in DLD-1 colon cancer cells in response to gamma interferon ( $\gamma$-IFN) and cancer cells in response to gamma interferon $(\gamma$-IFN) and tumor

24 Biancone L, Ebert EC, Das KM. The Mr 40,000 colonic protein is associated with antibody-dependent cell-mediated
cytolysis (ADCC) by ulcerative colitis (UC) sera. Gastroenterology 1990; 98: A159. 